\title{
Housing Price Index, Wealth, and Protective Shield against Covid-19
}

\author{
Mihai Pichler' ${ }^{1}$, Florin Skutnik², Aurel Vlad ${ }^{3}$, Hossein Shahri $^{4}$, Muhammad Ridwan $^{5}$ \\ ${ }^{1,2}$ Department of Sociology, University of Bucharest, Romania \\ ${ }^{3}$ Economic Research Center, University of Cyprus, Cyprus \\ ${ }^{4}$ Department of Environment, Texas Tech University, USA \\ ${ }^{5}$ Universitas Islam Negeri Sumatera Utara, Indonesia \\ mihai.pichler@upb.edu.ro,florin.skutnik@upb.edu.ro,aurel.vlad@ucy.edu.cy,hossein.shahri@ttu.edu, \\ bukharyahmedal@gmail.com
}

\section{Abstract}

This paper aims to fill two purposes: 1) we document that housing price index between different cities have intercorrelation. This means that when the housing price in one city goes up the other city follows. However, in the case of a big city and a small city, the housing price index of small city follows the path of housing price index in the small city. 2) The housing price index is a measure of wellbeing and wealth of residents. At the onset of a pandemic, wealthy and richer people have a wealthprotective shield against the disease. We show that this is the case in the US. We document that higher housing price indexes are associated with lower confirmed case of Covid-19 and lower risks of death due to the disease.
Keywords

housing price index, VARmodel; time series, covid-19; health; panel data

\section{Introduction}

Housing Market and its price dynamics is one of the heavily studied topic in Macroeconomic literature. (Iacoviello, 2005) shows that with financial frictions on the firm side, housing market output is subject to aggregate economic disturbance. This suggests an aggregate economic activity dictating housing market dynamics. (Iacoviello \& Neri, 2010) argues that over the business cycle, housing demand and housing technology shocks can be mostly associated with housing market dynamics. However, they also argue that since turn of the century, monetary factors have started to play a bigger role in the housing cycle. (Vladimir Valentinovich Kozhevnikov, 2020) discusses ripple effect attributed to spatialspillovers across regions in short run and convergence to some equilibrium over long term. This paper is in line with the (Azulaidin, 2020) and tries to see the short and long run relationship between two cities close to each other in the US.

In this study, we use time series and panel data analysis to study housing price index in two different contexts. First, we document that housing price index between different cities have inter-correlation. This means that when the housing price in one city goes up the other city follows. However, in the case of a big city and a small city, the housing price index of small city follows the path of housing price index in the small city. Second, the housing price index is a measure of wellbeing and wealth of residents. At the onset of a pandemic, wealthy and richer people have a wealth-protective shield against the disease. We show that this is the case in the US. We document that higher housing price indexes are associated with lower confirmed case of Covid-19 and lower risks of death due to the disease. 


\section{Review of Literatures}

Housing market affects many aspects in our life. (Hsu et al., 2018) show that the unemployment insurance benefits have the potential to stabilize the housing market. Those laid off workers who are exposed to higher rates of unemployment insurance compared to those who are not laid off reveal lower likelihood of mortgage delinquency. (NoghaniBehambari et al., 2020) uses changess in housing price index as a shock to relocation of families to hotter areas and show that temperature actually affects the outbreak of Covid-19. Similar studies also confirm this fact (Babacar Diakhaté, 2020, 2020; Butsic et al., 2011; Case et al., 2002; Chiappori et al., 2009; Chowdhury \& Maclennan, 2014; Cut Alma Nuraflah, 2020; Feler \& Senses, 2017; Iacoviello, 2005; İşleyen \& Hassoo, 2020; Luttmer \& Singhal, 2011; Meen, 1999; Phillips et al., 2020).

\section{A Theoretical Framework}

Changes in regional house prices, apart from factors such as the financial- monetary policy and aggregate economic disturbances, are often subject to regional factors. Meen (1999) suggests the movement of prices across regions to be decomposed into three components.

- Movements that are common to all regions;

- Variations that are due to the repressors, reflecting differences in economic growth between regions;

- Structural differences in regional housing markets, captured by spatial coefficient heterogeneity.

I use VAR models to analyze the ripple effect between two cities in Northwest Texas- Lubbock and Midland. Lubbock is an economic hotspot for the Northwest region of Texas, while Midland is rich in oil resources and is one of the growing cities in the region. By using the VAR model we try to test the second and the third point by Meen (1999). The basic understanding is that if changes in the housing prices are first seen in Lubbock and are gradually diffused towards Midland (ie lag of housing price in Lubbock is statistically significant for housing prices in Midland), then we can hold the second point of Meen (1999) to be true. This concludes that there is a spatial spillover caused by migration, equity transfer, spatial arbitrage and spatial patterns. However, if lag of housing prices in Midland is statically signifant for housing prices in Lubbock, that can be explained by the third point of Meen (1999) and hence we can conclude that there must be some structural difference in these housing market causing the movement in the price

\section{Research Methods}

Time series data from Fred economic data is taken for the MSA region. From the data on the prices, we then generate growth rate in the prices for the two regions. The growth rate is then used for the VAR analysis. The panel data for the analysis on novel coronavirus comes from NoghaniBehambari et al. (2020). The daily count of new confirmed cases and death due to covid-19 is extracted from USA-Facts (2020). The daily temperature data, also used as control variable in all regression, is extracted from the Global Summary of the Day data files produced by the National Oceanic and Atmospheric Administration (NOAA). The county population and demographic data are extracted from SEER (2019). The county average wage data is from the Quarterly Census of Employment and Wages (QCEW). Finally, the unemployment rate data is extracted from Local Area Unemployment Statistics gathered by the Bureau of Labor Statistics. The Income and Gross State Product is extracted from (Makinde, 2020). 


\section{Empirical Method}

We use the following empirical method.

$$
y_{c s t}=\alpha_{0}+\alpha_{1} \text { Housing Price } e_{c s, t}+\alpha_{2} T_{c s, t}+\phi_{c}+\gamma_{s t}+\eta_{t}+\gamma_{c} \times t+\epsilon_{c s t}
$$

Where y is death rate due to Covid-19 or confirmed cases of Covid-19 in county $c$ in state $s$ and time $t . T$ is temperature. $\phi$ is county fixed effect. $\gamma$ is state by month fixed effect. $\eta$ is time fixed effect. $\epsilon$ is error term. A summary statistics of the panel sample is reported in table 1.

Table 1. Sumarry Statistic

\begin{tabular}{lccccc}
\hline Variable & Observations & Mean & Std. Dev. & Min & Max \\
\hline Covid-19 Monthly Death Rate & 34,474 & 0.231 & 0.583 & 0 & 17.627 \\
Covid-19 Total Death Rate & 34,474 & 115.037 & 87.261 & 0 & 834.598 \\
Covid-19 Monthly Confirmed Cases Rate & 34,474 & 13.46 & 24.191 & 0 & 608.331 \\
Covid-19 Total Confirmed Cases Rate & 34,474 & 6590.289 & 2811.116 & 0 & 27388.221 \\
\%Manufacturing Employment & 34,474 & 0.033 & 0.028 & 0 & 0.193 \\
\%Mining Employment & 34,474 & 0.013 & 0.02 & 0 & 0.247 \\
\%Construction Employment & 34,474 & 0.013 & 0.01 & 0 & 0.216 \\
\%Blacks & 34,474 & 9.912 & 14.6 & 0 & 86.391 \\
\%Whites & 34,474 & 85.845 & 16.221 & 9.27 & 99.454 \\
\%Males & 34,474 & 50.102 & 2.241 & 42.996 & 73.425 \\
\%Aged 25-65 & 34,474 & 50.265 & 3.167 & 28.821 & 72.653 \\
Average Weekly Wages & 34,474 & 768.784 & 174.289 & 436.67 & 2430.1 \\
Unemployment Rate & 34,474 & 7.063 & 3.971 & 0.4 & 41 \\
Average Housing Price Index & 34,474 & 156.598 & 259.657 & 89.573 & 897.249 \\
\hline
\end{tabular}

Table 2. Housing Price Index and the Outbreak of Covid-19

\begin{tabular}{lccccccc}
\hline & \multicolumn{3}{c}{ Covid-19 Death Rate } & & \multicolumn{3}{c}{ Covid-19 Case Rate } \\
\cline { 2 - 3 } & $(1)$ & $(2)$ & $(3)$ & & $(4)$ & $(5)$ & $(6)$ \\
\hline Average Housing & $-0.020^{* * *}$ & $-0.024^{* * *}$ & $-0.026^{* * *}$ & & $-2.115^{* * *}$ & $-3.826^{* * *}$ & $-3.967^{* * *}$ \\
Price Index & $(0.004)$ & $(0.004)$ & $(0.005)$ & & $(0.356)$ & $(0.584)$ & $(0.595)$ \\
& & & & & & & \\
\hline State FE & Yes & Yes & Yes & & Yes & Yes & Yes \\
Year FE & Yes & Yes & Yes & & Yes & Yes & Yes \\
State Trend & No & Yes & Yes & & No & Yes & Yes \\
State Controls & No & No & Yes & & No & No & Yes \\
$R^{2}$ & 0.133 & 0.162 & 0.184 & & 0.348 & 0.413 & 0.440 \\
Observations & 34,474 & 34,474 & 34,474 & & 34,474 & 34,474 & 34,474 \\
\hline
\end{tabular}

Notes. Standard errors are reported in parenthesis and clustered at the state level. County-by-year controls include: unemployment rate, share of black population, share of white population, share of male population, share of population aged 25-65; share of manufacturing employment, share of mining employment, share of construction employment; average weekly wages; personal income per capita; log of total wages; per capita earnings, rent, dividend, and unemployment insurance benefits. State-by-year controls include: a series of dummies to capture the passage of Affordable Care Act; Gross State Product per capita; union coverage rate; Medicaid coverage rate; and a series of dummies to capture any welfare reforms over the sample period. All dollar values are converted into 2017 real dollars 


\section{Results and Discussion}

\subsection{Price Movements}

This section discusses the results of the analysis of the housing prices at Lubbock and midland. The following figure shows the housing pricing (level and percentage growth) changes throughout time (refer to figure 1).

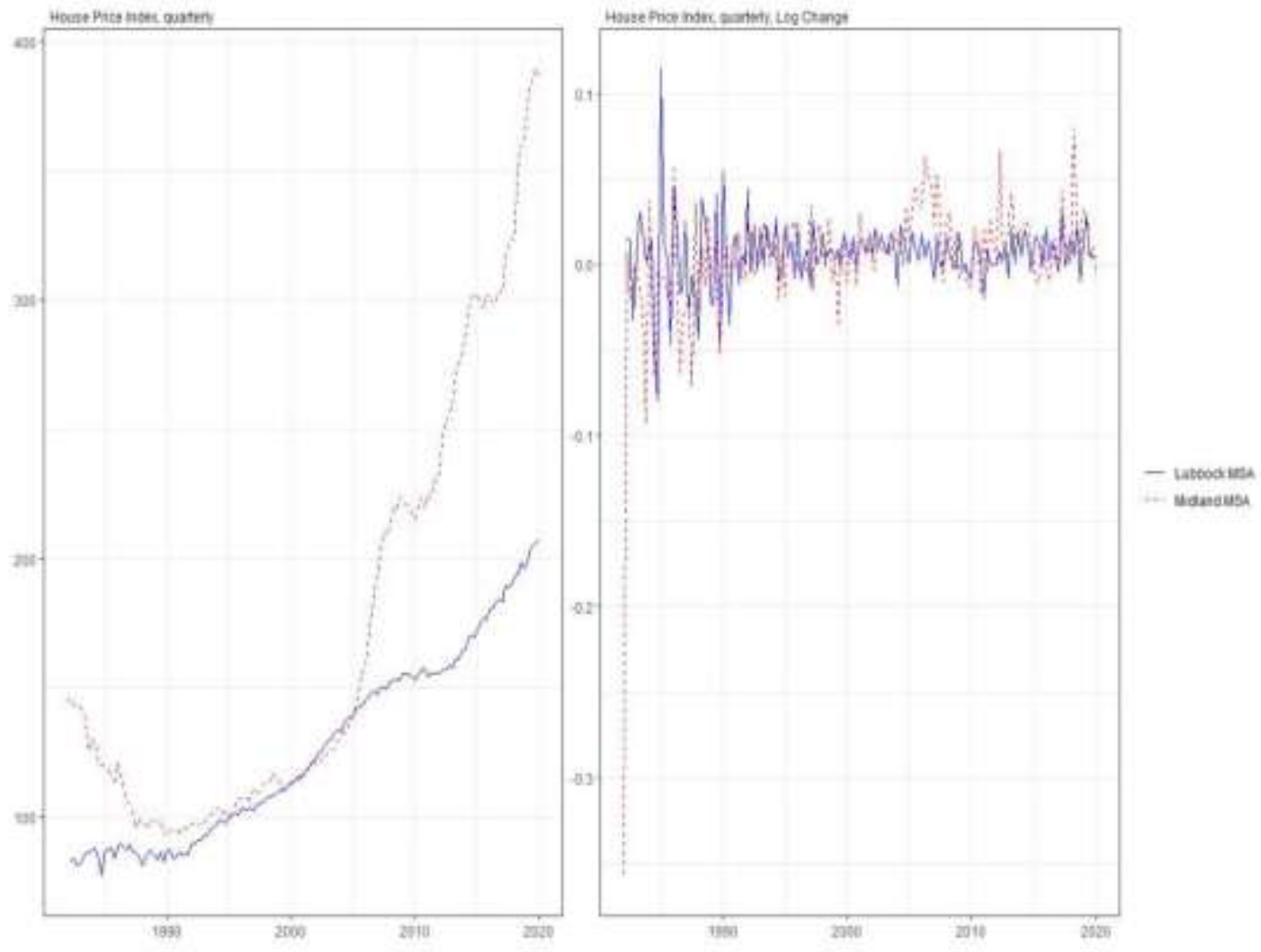

Figure 1. The Trend and Change in Housing Price Index in Midland and Lubbock

It can be seen that although Lubbock is the economic hub in the region, Midland has seen substantial growth in the prices especially after 2005. It can be seen that there is higher percentage change in the midland prices and is more volatile market when compared against Lubbock. This it is in contrast with previous literature where housing prices are higher in the economic zones with better health care, personal income and political influence. Here, although Lubbock is the center of economic activities, housing price in Midland is higher. So, we use the simple VAR analysis to see if prices in Lubbock actually diffuse to Midland, or it is not the case.

\subsection{VAR Analysis}

I use the VAR analysis with two approach. In the first approach we estimate the numbers of lags we should use in the VAR model by estimating information criteria and final prediction error for sequential increasing the lag order up to a VAR(p)-process. Which are based on the same sample size. We get the following results (refer to figure 2). 


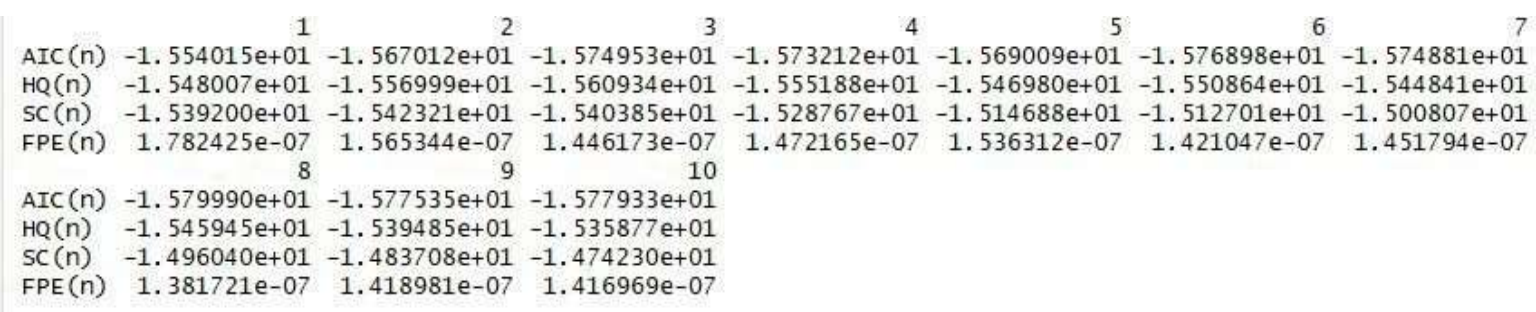

Figure 2. VAR (p) Process Results

We use HQ method to determine the lags, we use to select 3 lags for the VAR analysis. For the second approach, we use VAR with no highest lag order for lag length selection. Here, we use AIC for choosing lags. The results of this is shown in the following table with two different lag selection (refer to figure 3 ).

\begin{tabular}{|c|c|c|c|c|}
\hline & \multicolumn{4}{|c|}{ Dependent variable: } \\
\hline & $\begin{array}{l}\text { LBK } \\
\text { (1) }\end{array}$ & $\begin{array}{l}\text { MID } \\
(2)\end{array}$ & $\begin{array}{l}\text { LBK } \\
\text { (3) }\end{array}$ & $\begin{array}{l}\text { MID } \\
(4)\end{array}$ \\
\hline LBK. 71 & $\begin{array}{c}-0.398^{* k *} \\
(0.096)\end{array}$ & $\begin{array}{r}-0.094 \\
(0.110)\end{array}$ & $\begin{array}{c}-0.301^{k * k} \\
(0.091)\end{array}$ & $\begin{array}{r}-0.088 \\
(0.106)\end{array}$ \\
\hline MID. 11 & $\begin{array}{c}0.145^{*} \\
(0.081)\end{array}$ & $\begin{array}{c}0.076 \\
(0.093)\end{array}$ & $\begin{array}{l}0.170^{2 * 8} \\
(0.080)\end{array}$ & $\begin{array}{l}0.206^{\text {k k }} \\
(0.094)\end{array}$ \\
\hline LBK. 12 & $\begin{array}{c}-0.332^{k+k x} \\
(0.098)\end{array}$ & $\begin{array}{l}-0.186^{\star x} \\
(0.112)\end{array}$ & & \\
\hline MID. 12 & $\begin{array}{r}-0.037 \\
(0.080)\end{array}$ & $\begin{array}{l}0.214^{* *} \\
(0.092)\end{array}$ & & \\
\hline LBK. 13 & $\begin{array}{l}-0.192^{\text {के }} \\
(0.095)\end{array}$ & $\begin{array}{r}-0.027 \\
(0.108)\end{array}$ & & \\
\hline const & $\begin{array}{l}0.010^{* k *} \\
(0.002)\end{array}$ & $\begin{array}{c}0.003 \\
(0.002)\end{array}$ & $\begin{array}{l}0.006^{\text {हh: }} \\
(0.002)\end{array}$ & $\begin{array}{c}0.004 \\
(0.002)\end{array}$ \\
\hline observations & 116 & 116 & 118 & 118 \\
\hline R2 & 0.202 & 0.206 & 0.100 & 0.041 \\
\hline Adjusted R2 & 0.158 & 0.163 & 0.085 & 0.025 \\
\hline Residuat std. Error & $0.020(\mathrm{df}=109)$ & $0.023(\mathrm{df}=109)$ & $0.021(\mathrm{df}=115)$ & $0.025(d f=115)$ \\
\hline F statistic & $4.602^{\text {*4: }}(d f=6 ; 109)$ & $4.720^{* k *}(\mathrm{df}=6 ; 109)$ & $6.402^{\text {*k }}(d f=2 ; 115)$ & $2.476^{*} \quad(\mathrm{df}=2 ; 115)$ \\
\hline
\end{tabular}

Figure 3. VAR AIC Results

In the table, column 1 and 2 shows the results from the first model with 3 lags, column 3 and 4 shows the results from the second model with just one lag. The first model is not very successful in determining the relationship between Lubbock and Midland prices. It shows that the lagged Lubbock prices are significant for housing prices of Lubbock and first lag of Midland prices is slightly significant. In Midland however, it is seen that former lagged prices are more significant than the recent lags in the housing prices and Lubbock prices are not as significant. The second model however gives a very interesting result. It is seen that in forecasting Lubbock prices, lagged Lubbock price is significant at $1 \%$ and even lagged Midland price is significant at 5\% level. However, for forecasting Midland price, lagged Lubbock price is insignificant and lagged Midland price is significant at $5 \%$ significant level.

As clearer picture is available using the second model. We use the second model to generate the following IRF (refer to figure 4). 

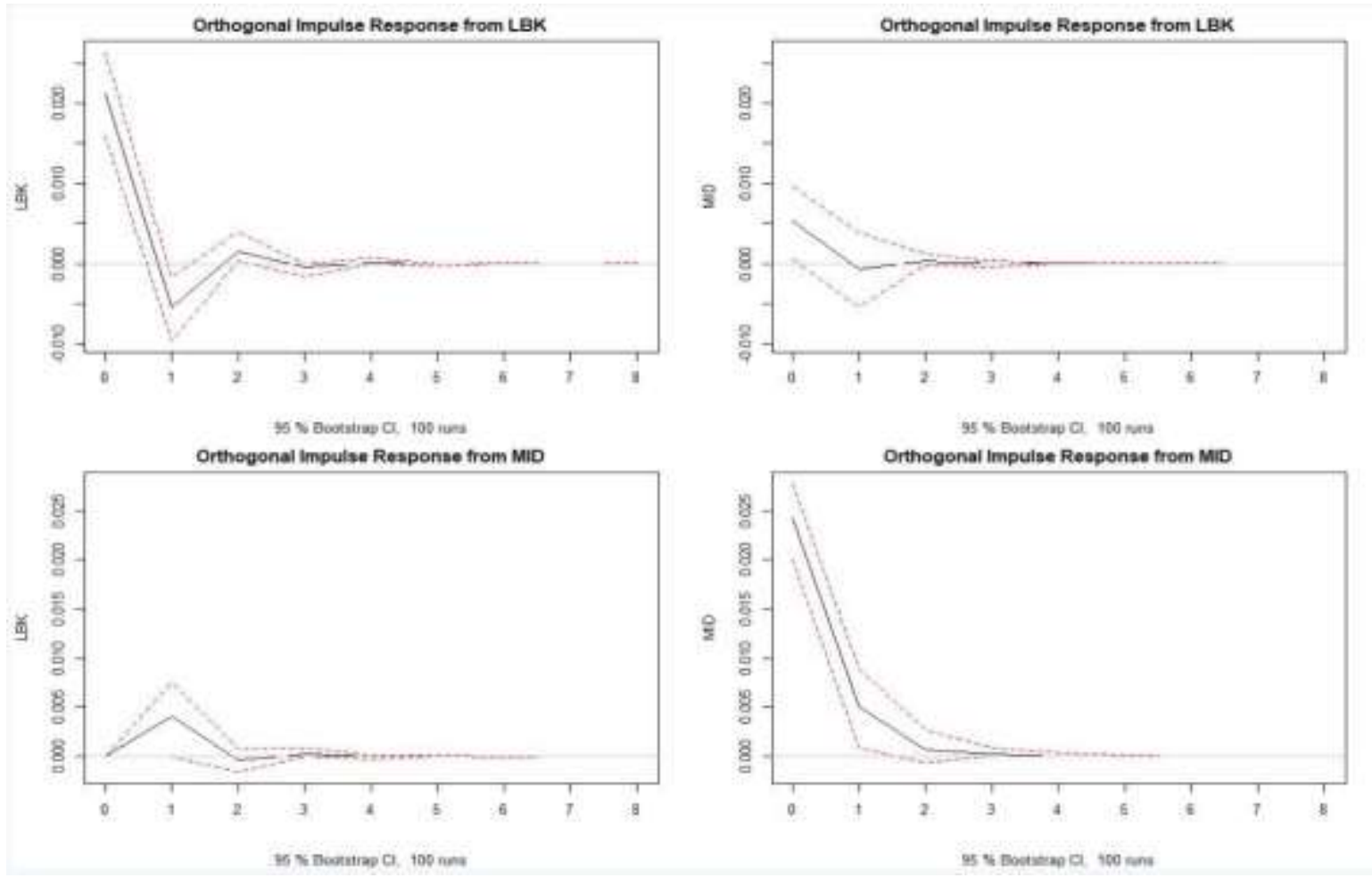

Figure 3. Orthogonal Impulse Response Results

\subsection{Panel Data Analysis}

Table 2 shows the main results for the panel data. If housing price index goes up by 10 percent, one can see that the death due to Covid-19 would go down by 0.26 per 1,000 population (column 3). In the same manner, if housing price index goes up by 10 percent, one can see that the confirmed cases due to Covid-19 would go down by 3.96 per 1,000 population. All the marginal effects are statistically significant and economically large.

\section{Conclusion}

The study of housing market and its different aspects is important for policymakers and has important policy implications. In this study, we used time series and panel data analysis to study housing price index in two different contexts. First, we document that housing price index between different cities have inter-correlation. This means that when the housing price in one city goes up the other city follows. However, in the case of a big city and a small city, the housing price index of small city follows the path of housing price index in the small city. Second, the housing price index is a measure of wellbeing and wealth of residents. At the onset of a pandemic, wealthy and richer people have a wealthprotective shield against the disease. We show that this is the case in the US. We document that higher housing price indexes are associated with lower confirmed case of Covid-19 and lower risks of death due to the disease. 


\section{References}

Azulaidin. (2020). Factors Affecting the Growth of the Agricultural Sector in Langkat Regency. Konfrontasi: Jurnal Kultural, Ekonomi Dan Perubahan Sosial, 7(4), 264274. https://doi.org/10.33258/konfrontasi2.v7i4.124

Babacar Diakhaté. (2020). Cultural Diversity, Ethnocentrism and Terrorism in Mukoma WA Ngugi's Black Star Nairobi (2013). Britain International of Humanities and Social Sciences (BIoHS) Journal, 2(2), 367-373. https://doi.org/10.33258/biohs.v2i2.234

Butsic, V., Hanak, E., \& Valletta, R. G. (2011). Climate change and housing prices: Hedonic estimates for ski resorts in western North America. Land Economics, 87(1), 75-91. https://doi.org/10.3368/le.87.1.75

Case, A., Lubotsky, D., \& Paxson, C. (2002). Economic status and health in childhood: The origins of the gradient. American Economic Review, 92(5), 1308-1334. https://doi.org/10.1257/000282802762024520

Chiappori, P. A., Iyigun, M., \& Weiss, Y. (2009). Investment in schooling and the marriage market. American Economic Review, 99(5), 1689-1713. https://doi.org/10.1257/aer.99.5.1689

Chowdhury, R. A., \& Maclennan, D. (2014). Regional house price cycles in the UK, 19782012: A Markov switching VAR. Journal of European Real Estate Research, 7(3), 345-366. https://doi.org/10.1108/JERER-02-2014-0014

Cut Alma Nuraflah. (2020). Communication Strategy of the Chinese Feather Village Towards Prosperous Village. Britain International of Humanities and Social Sciences (BIoHS) Journal, 2(2), 374-380. https://doi.org/10.33258/biohs.v2i2.235

Feler, L., \& Senses, M. Z. (2017). Trade shocks and the provision of local public goods. American Economic Journal: Economic Policy, 9(4), 101-143. https://doi.org/10.1257/pol.20150578

Hsu, J. W., Matsa, D. A., \& Melzer, B. T. (2018). Unemployment insurance as a housing market stabilizer. American Economic Review, 108(1), 49-81. https://doi.org/10.1257/aer.20140989

Iacoviello, M. (2005). House prices, borrowing constraints, and monetary policy in the business cycle. In American Economic Review (Vol. 95, Issue 3, pp. 739-764). https://doi.org/10.1257/0002828054201477

Iacoviello, M., \& Neri, S. (2010). Housing market spillovers: Evidence from an estimated DSGE model. American Economic Journal: Macroeconomics, 2(2), 125-164. https://doi.org/10.1257/mac.2.2.125

İşleyen, Ş., \& Hassoo, A. K. (2020). The Impact of the University in Increasing the Book Reading on Students: Case Study Soran University. SIASAT, 5(4), 51-58. https://doi.org/10.33258/siasat.v5i4.70

Luttmer, E. F. P., \& Singhal, M. (2011). Culture, context, and the taste for redistribution. American Economic Journal: Economic Policy, 3(1), 157-179. https://doi.org/10.1257/pol.3.1.157

Makinde, O. O. (2020). Prefiguring Housing Quality in Urban Communities in Ibadan Nigeria. SIASAT, 5(4), 65-76. https://doi.org/10.33258/siasat.v5i4.72

Meen, G. (1999). Regional house prices and the ripple effect: A new interpretation. Housing Studies, 14(6), 733-753. https://doi.org/10.1080/02673039982524

NoghaniBehambari, H., Salari, M., Noghani, F., \& Tavassoli, N. (2020). The Effect of Temperature on COVID-19 Confirmed Cases: Evidence from US Counties. SSRN Electronic Journal. https://doi.org/10.2139/ssrn.3636662 
Phillips, S. C.-, Deb Proshad Halder, Serlange Campbell, \& Daneil Phillips. (2020). Cross Cultural Differences in Cognition: A Study on How Culture Affects the Way We Think. SIASAT, 5(3), 9-15. https://doi.org/10.33258/siasat.v5i3.64

SEER. (2019). Surveillance, Epidemiology, and End Results (SEER) Program (www.seer.cancer.gov) Research Data (1975-2016). National Cancer Institute, DCCPS, Surveillance Research Program.

USA-Facts. (2020). US Coronavirus Cases and Deaths | USAFacts. https://usafacts.org/visualizations/coronavirus-covid-19-spread-map

Vladimir Valentinovich Kozhevnikov. (2020). About Some Actual Problems of the Methodology of Research of State Legal Phenomena. Konfrontasi: Jurnal Kultural, Ekonomi Dan Perubahan Sosial, 7(4), 275-281. https://doi.org/10.33258/konfrontasi2.v7i4.125 